\title{
Isolation of Five New Flavonoids from Melicope triphylla
}

\author{
Matsutake Higa, Megumi Imamura, Kazuhito Ogihara, and Toshimasa Suzuka* \\ College of Science, University of the Ryukyus; Nishihara, Okinawa 903-0213, Japan. \\ Received October 25, 2012; accepted February 1, 2013
}

Five new flavonoids, 5,8-dihydroxy-3,7-dimethoxy-3',4'-methylenedioxyflavone (1), 7-hydroxy-3,5-dimethoxy-3',4'-methylenedioxyflavone (2), 7-(2,3-dihydroxy-3-methylbutoxy)-3,5-dimethoxy-3',4'-methylenedioxyflavone (3), 7-(2,3-dihydroxy-3-methylbutoxy)-3,3',4',5-tetramethoxyflavone (4), and 7-(2,3-dihydroxy-3methylbutoxy)-3, $3^{\prime}, 4^{\prime}, 5,8$-pentamethoxyflavone (5), were isolated from the leaves of Melicope triphylla. In addition, six known flavonoids were detected: 3,4',5-trihydroxy-3',7,8-trimethoxyflavone (6), 5,7-dihydroxy-3methoxy-3', $4^{\prime}$-methylenedioxyflavone (7), 4',5,7-trihydroxy-3, $3^{\prime}$-dimethoxyflavone $(8), 4^{\prime}, 7$-dihydroxy-3, $3^{\prime}, 5,8$ tetramethoxyflavone (9), 4',7-dihydroxy-3,3',5-trimethoxyflavone (10), and $4^{\prime}, 5,7$-trihydroxy-3,3',8-trimethoxyflavone (11). The new compound structures were determined by spectroscopic methods. Compounds 1-5 did not exhibit any ichthyotoxic activity against Japanese killifish (medaka in Japanese) (Oryzias latipes var.) at $10 \mathrm{ppm}$.

Key words Melicope triphylla; Rutaceae; prenylated flavonoid; ichthyotoxic activity

Melicope triphylla MERr. (Rutaceae) (Awadan in Japanese), a small evergreen tree, is widely distributed in Southeast Asia and is the only species of Melicope native to Japan. Many flavonoids have been isolated from the leaves, ${ }^{1-4)}$ root, and stem bark $^{1,5,6)}$ of this plant. Some have been reported to show antiplatelet aggregation, ${ }^{2,6)}$ ichthyotoxic, ${ }^{3)}$ cytotoxic, ${ }^{4)}$ and vasorelaxation activities. $\left.{ }^{6}\right)$ We have re-examined the constituents of this plant to obtain new biologically active flavonoids. Previously, we reported the isolation of ten new flavonoids. ${ }^{7,8)}$ In a follow-up investigation, we obtained five new compounds, 1-5, and six known compounds, 6-11, from the leaves. In this study, we report the isolation and structure elucidation of the new compounds and those ichtyotoxicities.

\section{Results and Discussion}

After chromatographic separation, the remaining fractions from the extraction and isolation previously described ${ }^{7}$ yielded six known compounds, 3,4',5-trihydroxy-3',7,8-trimethoxyflavone (6), ${ }^{9)}$ 5,7-dihydroxy-3-methoxy-3',4'-methylenedioxyflavone (7), ${ }^{10)} \quad 4^{\prime}, 5,7$-trihydroxy-3,3'-dimethoxyflavone $(\mathbf{8}){ }^{11)} 4^{\prime}, 7$-dihydroxy-3,3',5,8-tetramethoxyflavone (9), ${ }^{12)}$ $4^{\prime}, 7$-dihydroxy-3,3',5-trimethoxyflavone (10), ${ }^{13)}$ and $4^{\prime}, 5,7$-trihydroxy-3,3',8-trimethoxyflavone (11), ${ }^{9)}$ and five new compounds, 1-5.

This is the first report of compound $\mathbf{7}$ as a natural product.

Compounds 1-5 showed positive responses to the magnesium-hydrochloric acid test for flavonoids. Additionally, their IR $(\alpha, \beta$-unsaturated carbonyl group) and UV spectral data (bands I and II) were typical of flavonoids.

Compound 1 was obtained as yellow needles (melting point (mp) $256-257^{\circ} \mathrm{C}$ ). Its molecular formula was determined to be $\mathrm{C}_{18} \mathrm{H}_{14} \mathrm{O}_{8}$ by high-resolution electrospray ionization mass spectrum (HR-ESI-MS) showing the pseudomolecular ion $[\mathrm{M}+\mathrm{H}]^{+}$at $m / z 359.0781$ (Calcd for $\mathrm{C}_{18} \mathrm{H}_{15} \mathrm{O}_{8}$ : 359.0767). The IR spectrum showed a band at $3300 \mathrm{~cm}^{-1}$, which was assigned to the hydroxyl group. In the UV spectrum of $\mathbf{1}$ in methanol, band I showed a large bathochromic shift $\left(\Delta \lambda_{\max }=60 \mathrm{~nm}\right)$ upon addition of an $\mathrm{AlCl}_{3}-\mathrm{HCl}$ mixture, suggesting the presence of a 5-hydroxyl group and the absence of an oxygen moiety at

The authors declare no conflict of interest
C-6. ${ }^{14)}$ The ${ }^{1} \mathrm{H}-\mathrm{NMR}$ spectrum of $\mathbf{1}$ (Table 1) revealed the presence of two methoxy groups $[3.79 \mathrm{ppm}(3 \mathrm{H}, \mathrm{s})$ and $3.89 \mathrm{ppm}$ $(3 \mathrm{H}, \mathrm{s})]$, one methylenedioxy group $[6.15 \mathrm{ppm}(2 \mathrm{H}, \mathrm{s})]$, one A-ring proton $[6.55 \mathrm{ppm}(1 \mathrm{H}, \mathrm{s})]$, and one hydrogen-bonded hydroxyl group [12.10 ppm $(1 \mathrm{H}, \mathrm{s}, \mathrm{OH}-5)]$. In addition, it displayed three ABX-type protons $[7.13 \mathrm{ppm}(1 \mathrm{H}, \mathrm{d}, J=8.0 \mathrm{~Hz}$, $\left.\mathrm{H}-5^{\prime}\right), 7.63 \mathrm{ppm}\left(1 \mathrm{H}, \mathrm{d}, J=2.0 \mathrm{~Hz}, \mathrm{H}-2^{\prime}\right)$, and $7.71 \mathrm{ppm}(1 \mathrm{H}$, $\left.\mathrm{dd}, J=2.0,8.0 \mathrm{~Hz}, \mathrm{H}-6^{\prime}\right)$ ], suggesting that $\mathrm{C}-3^{\prime}$ and $\mathrm{C}-4^{\prime}$ were substituted in the B-ring. The electron ionization (EI)-MS spectrum showed a diagnostic peak at $\mathrm{m} / \mathrm{z} 149$ corresponding to the $\left(\mathrm{OCH}_{2} \mathrm{O}\right) \mathrm{C}_{6} \mathrm{H}_{3}-\mathrm{C} \equiv \mathrm{O}^{+}$fragment, consistent with a $3^{\prime}, 4^{\prime}$-methylenedioxy substitution pattern in the B-ring. ${ }^{15)}$ The ${ }^{13} \mathrm{C}-\mathrm{NMR}$ spectrum (Table 2) showed one methoxy carbon signal resonating at lower magnetic field $(59.8 \mathrm{ppm})$. This suggested that both positions ortho to the methoxy group were substituted. ${ }^{16-19)}$ The carbon shifts of $\mathrm{OCH}_{3}$ substituents usually occur between 55.0 and $56.5 \mathrm{ppm}$ but in some cases they are observed further downfield between 59.5 and $63.0 \mathrm{ppm}$. This deshielding effect is seen only when the $\mathrm{OCH}_{3}$ is diortho substituted by two bulky substituents such as ring junction. Therefore, the signal was assigned to the 3-methoxy group. It also exhibited a signal for another methoxy carbon at higher magnetic field $(56.4 \mathrm{ppm})$, which suggested that only one or no position ortho to this methoxy group was substituted. ${ }^{16-19)}$ This signal was assigned to the A-ring methoxy group. The heteronuclear multiple-bond correlation (HMBC) spectrum of 1 (Fig. 1) showed long-range correlations between the A-ring proton and $\mathrm{C}-10$, indicating that the A-ring proton is located at $\mathrm{C}-6$ or $\mathrm{C}-8$. Thus, the substitution pattern in the A-ring is 5,6-dihydroxy-7-methoxy or 5,8-dihydroxy-7-methoxy. The ${ }^{13} \mathrm{C}-\mathrm{NMR}$ chemical shifts assigned to the A-ring of $\mathbf{1}$ agreed well with the ${ }^{13} \mathrm{C}$-NMR spectrum of 5,8 -dihydroxy-3,4',7trimethoxyflavone, ${ }^{20)}$ suggesting that the substitution pattern in the A-ring is 5,8-dihydroxy-7-methoxy. The nuclear Overhauser enhancement spectroscopy (NOESY) spectrum showed a relationship between the A-ring proton and both the $\mathrm{OCH}_{3}-7$ and $\mathrm{OH}-5$ protons (Fig. 1), confirming that the A-ring proton is located at C-6. Therefore, $\mathbf{1}$ was characterized as 5,8-dihydroxy-3,7-dimethoxy-3',4'-methylenedioxyflavone. All correlations in the HMBC spectrum (Fig. 1) were in complete agreement with the proposed structure. 
<smiles>COc1cc(O)c2c(=O)c(OC)c(-c3ccc4c(c3)OCO4)oc2c1O</smiles>

1<smiles>COc1ccc(-c2oc3c(OC)c(OCC(O)C(C)(C)O)cc(OC)c3c(=O)c2OC)cc1OC</smiles>

5<smiles>COc1cc(-c2oc3c(OC)c(O)cc(OC)c3c(=O)c2OC)ccc1O</smiles>

9<smiles>COc1c(-c2ccc3c(c2)OCO3)oc2cc(O)cc(OC)c2c1=O</smiles>

2<smiles>COc1cc(-c2oc3c(OC)c(OC)cc(O)c3c(=O)c2O)ccc1O</smiles>

6<smiles>COc1cc(-c2oc3cc(O)cc(OC)c3c(=O)c2OC)ccc1O</smiles>

10<smiles>COc1c(-c2ccc3c(c2)OCO3)oc2cc(O[CH+]C(O)C(O)(F)F)cc(OC)c2c1=O</smiles>

3<smiles>COc1c(-c2ccc3c(c2)OCO3)oc2cc(O)cc(O)c2c1=O</smiles>

7<smiles>COc1cc(-c2oc3c(OC)c(O)cc(O)c3c(=O)c2OC)ccc1O</smiles>

11<smiles>COc1ccc(-c2oc3cc(OCC(O)C(C)(C)O)cc(OC)c3c(=O)c2OC)cc1OC</smiles>

4<smiles>COc1cc(-c2oc3cc(O)cc(O)c3c(=O)c2OC)ccc1O</smiles>

8

Chart 1

Table 1. ${ }^{1} \mathrm{H}-\mathrm{NMR}$ Spectral Data for Compounds 1-5 (500 MHz, $\left.\delta\right)$

\begin{tabular}{|c|c|c|c|c|c|}
\hline & $\mathbf{1}^{a)}$ & $2^{a)}$ & $3^{b)}$ & $4^{b)}$ & $5^{b)}$ \\
\hline H-6 & $6.55(\mathrm{~s})$ & $6.38(\mathrm{~d}, 2.0)$ & $6.34(\mathrm{~d}, 2.0)$ & $6.36(\mathrm{~d}, 2.0)$ & $6.42(\mathrm{~s})$ \\
\hline $\mathrm{H}-8$ & & $6.51(\mathrm{~d}, 2.0)$ & $6.49(\mathrm{~d}, 2.0)$ & $6.52(\mathrm{~d}, 2.0)$ & \\
\hline H-2' & $7.63(\mathrm{~d}, 2.0)$ & $7.53(\mathrm{~d}, 2.0)$ & $7.59(\mathrm{~d}, 2.0)$ & $7.69(\mathrm{~d}, 2.0)$ & $7.82(\mathrm{~d}, 2.0)$ \\
\hline $\mathrm{H}-5^{\prime}$ & $7.13(\mathrm{~d}, 8.0)$ & $7.10(\mathrm{~d}, 8.0)$ & $6.92(\mathrm{~d}, 8.0)$ & $6.97(\mathrm{~d}, 8.5)$ & $7.01(\mathrm{~d}, 8.5)$ \\
\hline $\mathrm{H}-6^{\prime}$ & $7.71(\mathrm{dd}, 2.0,8.0)$ & $7.59(\mathrm{dd}, 2.0,8.0)$ & $7.66(\mathrm{dd}, 2.0,8.0)$ & $7.70(\mathrm{dd}, 2.0,8.5)$ & $7.84(\mathrm{dd}, 2.0,8.5)$ \\
\hline \multirow[t]{2}{*}{$\mathrm{H}-1^{\prime \prime}$} & & & $4.10(\mathrm{dd}, 8.0,9.5)$ & $4.11(\mathrm{dd}, 8.0,9.5)$ & $4.22(\mathrm{dd}, 7.0,9.5)$ \\
\hline & & & $4.23(\mathrm{dd}, 3.0,9.5)$ & $4.24(\mathrm{dd}, 3.0,9.5)$ & $4.39(\mathrm{dd}, 2.5,9.5)$ \\
\hline $\mathrm{H}-2^{\prime \prime}$ & & & $3.88(\mathrm{dd}, 3.0,8.0)$ & $3.88(\mathrm{dd}, 3.0,8.0)$ & $3.83(\mathrm{dd}, 2.5,7.0)$ \\
\hline $\mathrm{H}-4^{\prime \prime}$ & & & $1.32(\mathrm{~s})^{c)}$ & $1.32(\mathrm{~s})^{c)}$ & $1.33(\mathrm{~s})^{c}$ \\
\hline $\mathrm{H}-5^{\prime \prime}$ & & & $1.37(\mathrm{~s})^{c)}$ & $1.37(\mathrm{~s})^{c)}$ & $1.37(\mathrm{~s})^{c)}$ \\
\hline $\mathrm{OH}-5$ & $12.10(\mathrm{~s})$ & & & & \\
\hline $\mathrm{OH}-8$ & $8.88(\mathrm{~s})$ & & & & \\
\hline $\mathrm{OCH}_{3}-3$ & $3.79(\mathrm{~s})$ & $3.72(\mathrm{~s})$ & $3.86(\mathrm{~s})$ & $3.87(\mathrm{~s})$ & $3.90(\mathrm{~s})$ \\
\hline $\mathrm{OCH}_{3}-5$ & & $3.81(\mathrm{~s})$ & $3.94(\mathrm{~s})$ & $3.95(\mathrm{~s})$ & $3.98(\mathrm{~s})$ \\
\hline $\mathrm{OCH}_{3}-7$ & $3.89(\mathrm{~s})$ & & & & \\
\hline $\mathrm{OCH}_{3}-8$ & & & & & $3.95(\mathrm{~s})$ \\
\hline $\mathrm{OCH}_{3}-3^{\prime}$ & & & & $3.96(\mathrm{~s})^{c)}$ & $3.967(\mathrm{~s})^{c}$ \\
\hline $\mathrm{OCH}_{3}-4^{\prime}$ & & & & $3.97(\mathrm{~s})^{c)}$ & $3.972(\mathrm{~s})^{c)}$ \\
\hline $\mathrm{OCH}_{2} \mathrm{O}-3^{\prime}, 4^{\prime}$ & $6.15(\mathrm{~s})$ & $6.14(\mathrm{~s})$ & $6.06(\mathrm{~s})$ & & \\
\hline
\end{tabular}

Mesurements $a$ ) in DMSO- $\left.d_{6}, b\right)$ in $\mathrm{CDCl}_{3}$. c) Signals with the same superscript may be interchanged.

Compound 2 was obtained as colorless needles. Its molecular formula was determined to be $\mathrm{C}_{18} \mathrm{H}_{14} \mathrm{O}_{7}$ by high resolutionelectro spray ionization (HR-ESI)-MS. The IR spectrum of 2 showed a band at $3125 \mathrm{~cm}^{-1}$, which was assigned to the hydroxyl group. In the UV spectrum of $\mathbf{2}$ in methanol, band II showed a bathochromic shift $\left(\Delta \lambda_{\max }=6 \mathrm{~nm}\right)$ upon $\mathrm{NaOAc}$ addition, suggesting the presence of a 7-hydroxyl group. ${ }^{14)}$ The ${ }^{1} \mathrm{H}-\mathrm{NMR}$ spectrum of $\mathbf{2}$ (Table 1) revealed the presence of two methoxy groups $[3.72 \mathrm{ppm}(3 \mathrm{H}, \mathrm{s})$ and $3.81 \mathrm{ppm}(3 \mathrm{H}$, $\mathrm{s})]$, one methylenedioxy group $[6.14 \mathrm{ppm}(2 \mathrm{H}, \mathrm{s})]$, and two meta-coupled A-ring protons $[6.38 \mathrm{ppm}(1 \mathrm{H}, \mathrm{d}, J=2.0 \mathrm{~Hz}, \mathrm{H}-6)$ and $6.51 \mathrm{ppm}(1 \mathrm{H}, \mathrm{d}, J=2.0 \mathrm{~Hz}, \mathrm{H}-8)]$. In addition, it displayed signals for three ABX type B-ring protons $[7.10 \mathrm{ppm}(1 \mathrm{H}$, $\left.\mathrm{d}, J=8.0 \mathrm{~Hz}, \mathrm{H}-5^{\prime}\right), 7.53 \mathrm{ppm}\left(1 \mathrm{H}, \mathrm{d}, J=2.0 \mathrm{~Hz}, \mathrm{H}-2^{\prime}\right)$, and $\left.7.59 \mathrm{ppm}\left(1 \mathrm{H}, \mathrm{dd}, J=2.0,8.0 \mathrm{~Hz}, \mathrm{H}-6^{\prime}\right)\right]$. The EI-MS spectrum showed a diagnostic peak at $\mathrm{m} / \mathrm{z} 149$ corresponding to the 
Table 2. ${ }^{13} \mathrm{C}-\mathrm{NMR}$ Spectral Data for Compounds $\mathbf{1}-\mathbf{5}(125 \mathrm{MHz}, \delta)$

\begin{tabular}{|c|c|c|c|c|c|}
\hline & $\mathbf{1}^{a)}$ & $2^{a)}$ & $3^{b)}$ & $4^{b)}$ & $5^{b)}$ \\
\hline $\mathrm{C}-2$ & 154.9 & 151.6 & 152.5 & 152.8 & 152.5 \\
\hline $\mathrm{C}-3$ & 137.9 & 140.6 & 141.2 & 141.2 & 141.0 \\
\hline C-4 & 178.5 & 172.5 & 174.1 & 174.0 & 174.2 \\
\hline $\mathrm{C}-5$ & 152.8 & 161.2 & 161.0 & 161.1 & 156.5 \\
\hline C-6 & 95.5 & 96.7 & 96.0 & 96.0 & 93.8 \\
\hline $\mathrm{C}-7$ & 154.2 & 163.1 & 162.8 & 162.8 & 155.2 \\
\hline C- 8 & 126.0 & 95.4 & 93.1 & 93.2 & 131.0 \\
\hline C-9 & 143.7 & 158.5 & 158.6 & 158.7 & 151.0 \\
\hline $\mathrm{C}-10$ & 104.5 & 107.8 & 109.6 & 109.7 & 110.0 \\
\hline $\mathrm{C}-1^{\prime}$ & 123.7 & 124.5 & 124.5 & 123.3 & 123.4 \\
\hline $\mathrm{C}-2^{\prime}$ & 108.1 & 108.2 & 108.4 & 111.3 & 111.0 \\
\hline C-3' & 147.6 & 148.0 & 147.9 & 148.8 & 148.7 \\
\hline$C-4^{\prime}$ & 149.6 & 149.4 & 149.4 & 151.0 & 151.0 \\
\hline$C-5^{\prime}$ & 108.6 & 109.0 & 108.4 & 110.9 & 111.0 \\
\hline$C-6^{\prime}$ & 123.8 & 123.3 & 123.1 & 121.7 & 121.8 \\
\hline $\mathrm{C}-1^{\prime \prime}$ & & & 69.7 & 69.7 & 71.5 \\
\hline $\mathrm{C}-2^{\prime \prime}$ & & & 75.8 & 75.8 & 75.4 \\
\hline$C-3^{\prime \prime}$ & & & 71.7 & 71.7 & 71.8 \\
\hline C-4" & & & 25.1 & 25.1 & 26.6 \\
\hline C-5" & & & 26.6 & 26.6 & 25.5 \\
\hline $\mathrm{OCH}_{3}-3$ & 59.8 & 59.8 & 59.9 & 59.9 & 59.9 \\
\hline $\mathrm{OCH}_{3}-5$ & & 56.3 & 56.4 & 56.4 & 56.6 \\
\hline $\mathrm{OCH}_{3}-7$ & 56.4 & & & & \\
\hline $\mathrm{OCH}_{3}-8$ & & & & & 61.7 \\
\hline $\mathrm{OCH}_{3}-3^{\prime}$ & & & & 56.0 & 55.9 \\
\hline $\mathrm{OCH}_{3}-4^{\prime}$ & & & & 56.1 & 56.0 \\
\hline $\mathrm{OCH}_{2} \mathrm{O}-3^{\prime}, 4^{\prime}$ & 102.0 & 102.2 & 101.6 & & \\
\hline
\end{tabular}

Mesurements $a$ ) in DMSO- $\left.d_{6}, b\right)$ in $\mathrm{CDCl}_{3}$.

$\left(\mathrm{OCH}_{2} \mathrm{O}\right) \mathrm{C}_{6} \mathrm{H}_{3}-\mathrm{C} \equiv \mathrm{O}^{+}$fragment, consistent with a $3^{\prime}, 4^{\prime}$-methylenedioxy substitution pattern in the B-ring. ${ }^{15)}$ It also showed a peak at $\mathrm{m} / \mathrm{z} 323$ corresponding to the $\left(\mathrm{M}^{+}-\mathrm{OH}_{3}\right)$ fragment, suggesting a 3,5-dimethoxy substitution pattern. ${ }^{15)}$ The ${ }^{13} \mathrm{C}$-NMR spectrum (Table 2) showed one methoxy carbon signal at $59.8 \mathrm{ppm}$, which was assigned to the 3-methoxy group by the same manner as $\mathbf{1}$. It also exhibited a signal for another methoxy carbon at $56.3 \mathrm{ppm}$, which was assigned to the 5methoxy group ${ }^{16-19)}$ by observation of a correlation between a singlet at $3.81 \mathrm{ppm}$ due to the methoxy proton and a signal at 161.2 ppm due to C-5 in the HMBC spectrum. This supported by the comparison of the chemical shifts for $\mathbf{2}$ with those described in literatures. ${ }^{16-19)}$ Therefore, 2 was characterized as 7-hydroxy-3,5-dimethoxy-3',4'-methylenedioxyflavone. All correlations in the HMBC spectrum (Fig. 1) were in complete agreement with the proposed structure.

Compound 3 was obtained as a colorless amorphous powder. Its molecular formula was determined to be $\mathrm{C}_{23} \mathrm{H}_{24} \mathrm{O}_{9}$ by HRESI-MS. Its spectral data were closely comparable to those of 2. The substitution pattern in the B-ring was determined to be $3^{\prime}, 4^{\prime}$-methylenedioxy by its ${ }^{1} \mathrm{H}-\mathrm{NMR}$ and EI-MS spectra by the same manner as $\mathbf{1}$ and $\mathbf{2}$. The ${ }^{1} \mathrm{H}-\mathrm{NMR}$ spectrum of $\mathbf{3}$ (Table 1) was similar to that of 2 , except for the presence of signals for the 2,3-dihydroxy-3-methylbutoxy group ${ }^{21)}$ on A ring [1.32, $1.37 \mathrm{ppm}$ (each $\left.3 \mathrm{H}, \mathrm{s},-\mathrm{OCH}_{2} \mathrm{CH}(\mathrm{OH}) \mathrm{C}\left(\mathrm{CH}_{3}\right)_{2} \mathrm{OH}\right), 3.88 \mathrm{ppm}$ $\left(1 \mathrm{H}, \mathrm{dd}, J=3.0,8.0 \mathrm{~Hz},-\mathrm{OCH}_{2} \mathrm{CH}(\mathrm{OH}) \mathrm{C}\left(\mathrm{CH}_{3}\right)_{2} \mathrm{OH}\right), 4.10 \mathrm{ppm}$ $\left(1 \mathrm{H}, \quad \mathrm{dd}, \quad J=8.0, \quad 9.5 \mathrm{~Hz}, \quad-\mathrm{OC} \underline{\mathrm{H}}_{2} \mathrm{CH}(\mathrm{OH}) \mathrm{C}\left(\mathrm{CH}_{3}\right)_{2} \mathrm{OH}\right)$, and $\left.4.23 \mathrm{ppm}\left(1 \mathrm{H}, \mathrm{dd}, J=3.0,9.5 \mathrm{~Hz},-\mathrm{OCH}_{2} \mathrm{CH}(\mathrm{OH}) \mathrm{C}\left(\mathrm{CH}_{3}\right)_{2} \mathrm{OH}\right)\right]$ in 3. The EI-MS spectrum showed a peak at $\mathrm{m} / \mathrm{z} 341$ that was assigned to the fragment ion produced by the loss of the 2,3-dihydroxy-3-methylbutyl radical from the molecular ion, confirming the presence of the 2,3-dihydroxy-3-methylbutoxy group. $^{22)}$ It also showed a peak at $\mathrm{m} / \mathrm{z} 425$ suggesting a 3,5-dimethoxy substitution pattern. ${ }^{15)}$ The ${ }^{13} \mathrm{C}-\mathrm{NMR}$ spectrum (Table 2) showed one methoxy carbon signal at $56.4 \mathrm{ppm}$, which was assigned to the 5-methoxy group. It also exhibited a signal for another methoxy carbon at $59.9 \mathrm{ppm}$, which was assigned to the 3-methoxy group. ${ }^{16-19)}$ The HMBC spectrum of 3 (Fig. 1) showed correlations between C-7 and three proton signals: the oxymethylene protons $\left(\mathrm{H}_{2}-1^{\prime \prime}\right), \mathrm{H}-6$, and $\mathrm{H}-8$, confirming that a prenyloxy group is located at C-7. Therefore, 3 was characterized as 7-(2,3-dihydroxy-3-methylbutoxy)-3,5dimethoxy-3',4'-methylenedioxyflavone. All correlations in the HMBC spectrum (Fig. 1) were in complete agreement with the proposed structure.

Compound 4 was obtained as a colorless amorphous powder. Its molecular formula was determined to be $\mathrm{C}_{24} \mathrm{H}_{28} \mathrm{O}_{9}$ by HR-ESI-MS. Its spectral data were closely comparable to those of $\mathbf{3}$. The ${ }^{1} \mathrm{H}-\mathrm{NMR}$ spectrum of $\mathbf{4}$ (Table 1) was similar to that of 3, except for the presence of two methoxy group signals $[3.96 \mathrm{ppm}(3 \mathrm{H}, \mathrm{s})$ and $3.97 \mathrm{ppm}(3 \mathrm{H}, \mathrm{s})]$ instead of the methylenedioxy group signal present in $\mathbf{3}$. The EI-MS spectrum showed fragment ion peaks at $\mathrm{m} / \mathrm{z} 411$ and 357 due to $\left[\mathrm{M}^{+}-\mathrm{OH}_{3}\right]$ and $\left[\mathrm{M}^{+}-\mathrm{C}_{5} \mathrm{H}_{11} \mathrm{O}_{2}\right]$ ions, respectively, suggesting the presence of a 3,5-dimethoxy substitution pattern $^{15)}$ and a 2,3-dihydroxy-3-methylbutyl group. ${ }^{22)}$ It also showed a diagnostic peak at $\mathrm{m} / \mathrm{z} 165$ corresponding to the $\left(\mathrm{OCH}_{3}\right)_{2} \mathrm{C}_{6} \mathrm{H}_{3}-\mathrm{C} \equiv \mathrm{O}^{+}$fragment, consistent with a $3^{\prime}, 4^{\prime}-$ dimethoxy substitution pattern in the B-ring. ${ }^{15)}$ The ${ }^{13} \mathrm{C}$-NMR spectrum (Table 2) showed three methoxy carbon signals at $56.0,56.1$, and $56.4 \mathrm{ppm}$, which were assigned to the $3^{\prime}-$, 4 '-, and 5-methoxy groups by observations of correlations 

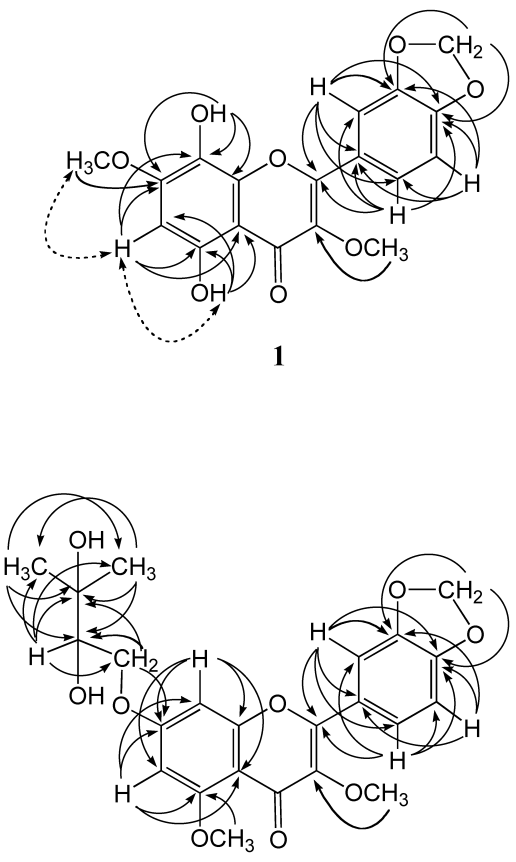

3

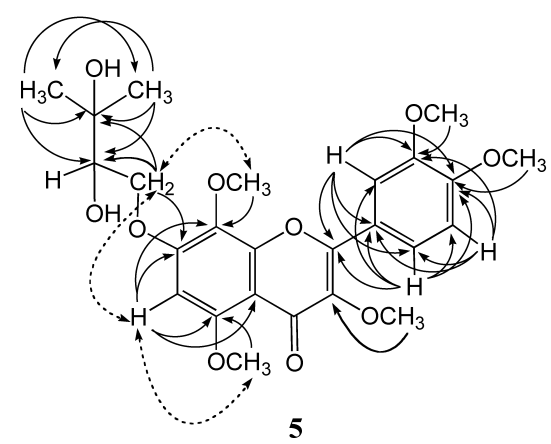

Fig. 1. Key HMBC Correlations $(\curvearrowright)$ and NOEs $(\sqrt{ })$ for Compounds 1-5

between each singlet due to methoxy proton and each signal due to corresponding carbon atoms bonded to the methoxy groups in HMBC spectrum of 4. It also exhibited a signal for another methoxy carbon at $59.9 \mathrm{ppm}$, which was assigned to the 3-methoxy group. ${ }^{16-19)}$ The HMBC spectrum of 4 (Fig. 1) showed correlations between $\mathrm{C}-7$ and three proton signals: the oxymethylene protons $\left(\mathrm{H}_{2}-1^{\prime \prime}, \mathrm{H}-6\right.$, and $\left.\mathrm{H}-8\right)$, confirming that a prenyloxy group is located at C-7. Therefore, 4 was characterized as 7-(2,3-dihydroxy-3-methylbutoxy)-3,3',4',5tetramethoxyflavone. All correlations in the HMBC spectrum (Fig. 1) were in complete agreement with the proposed structure.

Compound 5 was obtained as a colorless amorphous powder. Its molecular formula was determined to be $\mathrm{C}_{25} \mathrm{H}_{30} \mathrm{O}_{10}$ by HR-ESI-MS. Its spectral data were closely comparable to those of 4. The substitution pattern in the B-ring was determined to be $3^{\prime}, 4^{\prime}$-dimethoxy by its ${ }^{1} \mathrm{H}-\mathrm{NMR}$ and EI-MS spectra by the same manner as $\mathbf{3}$ and $\mathbf{4}$. The ${ }^{1} \mathrm{H}-\mathrm{NMR}$ spectrum of 5 (Table 1) was similar to that of $\mathbf{4}$, except for the presence of one methoxy group signal $[3.95 \mathrm{ppm}(3 \mathrm{H}, \mathrm{s})]$ instead of one of the two A-ring proton signals in 4. The EI-MS spectrum
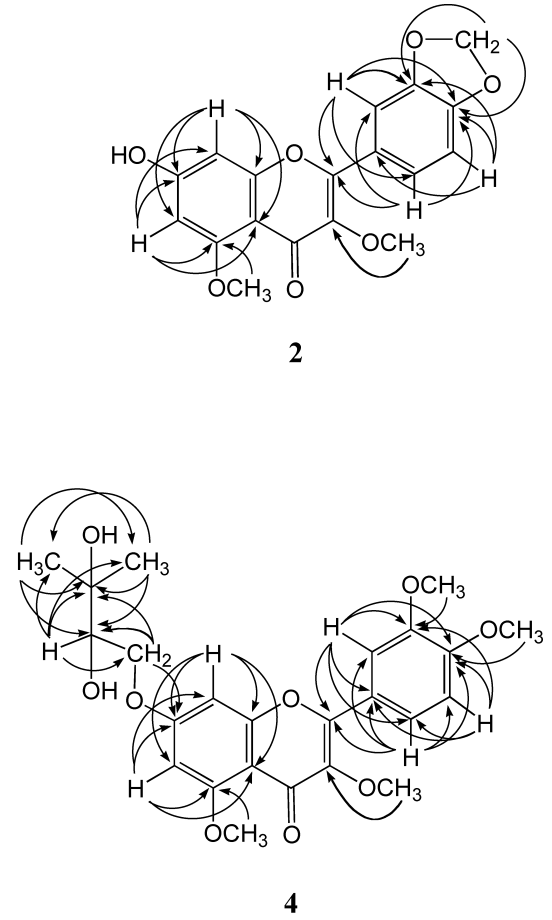

suggested the presence of the 2,3-dihydroxy-3-methylbutyl group $\left(\mathrm{m} / \mathrm{z} 387, \mathrm{M}^{+}-\mathrm{C}_{5} \mathrm{H}_{11} \mathrm{O}_{2}\right)^{22)}$ and a 3,5-dimethoxy substitution pattern $\left.\left(m / z 471, \mathrm{M}^{+}-\mathrm{OH}_{3}\right) \cdot{ }^{15}\right)$ The ${ }^{13} \mathrm{C}-\mathrm{NMR}$ spectrum (Table 2) showed five methoxy carbon signals, 55.9, 56.0, $56.6,59.9$, and $61.7 \mathrm{ppm}$. The signals of 55.9, 56.0, 56.6, and $59.9 \mathrm{ppm}$ were assigned to the $3^{\prime}-, 4^{\prime}, 5-$, and 3-methoxy groups, respectively, by the same manner as $\mathbf{3}$ and $\mathbf{4}$. The remaining methoxy group was assigned to A-ring by observation of a fragment ion peak at $m / z 165$ due to $\left[\left(\mathrm{CH}_{3} \mathrm{O}\right)_{2} \mathrm{C}_{6} \mathrm{H}_{3}-\right.$ $\left.\mathrm{C} \equiv \mathrm{O}^{+}\right]$ion corresponding to B-ring in the EI-MS spectrum. The HMBC spectrum of 5 (Fig. 1) showed a correlation between the A-ring proton and $\mathrm{C}-10$, indicating that the A-ring proton is located at either C-6 or C-8. Thus, the substitution pattern in the A-ring is 6-(2,3-dihydroxy-3-methylbutoxy)-5,7dimethoxy or 7-(2,3-dihydroxy-3-methylbutoxy)-5,8-dimethoxy. The ${ }^{13} \mathrm{C}-\mathrm{NMR}$ chemical shifts assigned to the A-ring of $\mathbf{5}$ agreed well with the ${ }^{13} \mathrm{C}-\mathrm{NMR}$ spectrum of 7-(2-hydroxy-3methylbut-3-enyloxy)-3,3',4',5,8-pentamethoxyflavone, ${ }^{8)}$ suggesting that the substitution pattern in the A-ring is 7-(2,3-dihydroxy-3-methylbutoxy)-5,8-dimethoxy. The NOESY spectrum (Fig. 1) showed a relationship between the A-ring proton 
and two proton groups: the oxymethylene protons $\left(\mathrm{H}_{2}-1^{\prime \prime}\right)$ and the methoxy group protons at $3.98 \mathrm{ppm}$. NOE effects were also observed between $\mathrm{H}_{2}-1^{\prime \prime}$ and $\mathrm{OCH}_{3}-8$ at $3.95 \mathrm{ppm}$, confirming that a prenyloxy group is located at C-7. Therefore, 5 was characterized as 7-(2,3-dihydroxy-3-methylbutoxy)-3,3', $4^{\prime}, 5,8$ pentamethoxyflavone. All correlations in the HMBC spectrum (Fig. 1) were in complete agreement with the proposed structure, although a part of correlativity of 2,3-dihydroxy3 -methylbutoxy was not observed. This is the first report of flavonoids bearing 2,3-dihydroxy-3-methylbutoxy substituent.

Compounds 1-5 did not display any ichthyotoxic activity against japanse killifishu (Oryzias latipes var.) when tested at $10 \mathrm{ppm}$, in spite that the activity was appeared by 3,3', 4',5-tetramethoxy-7-(3-methylbut-3-enyloxy)flavone which isolated from this plant at the same concentration. ${ }^{8)}$ The reason for these facts seem to be due to the presence of hydroxyl substituents at C-5, C-7, C-8, C-2", or C-3". On the basis of the results in this study and in previous experiment, ${ }^{8)}$ the hydroxy group at $\mathrm{C}-2^{\prime \prime}$ was judged to have no effect on the ichthyotoxicity. Therefore, the absolute configuration at C-2" in 3-5 were not determined by this research as well as the previous research. Further extensive scope for the determination of stererochemistry of the 3-5 and the evaluation to the other biological activities are in progress in our lab.

\section{Experimental}

General Procedures Melting points were measured on a Yanagimoto micro melting point apparatus MP-S3 and were not corrected. IR spectra were acquired using a JASCO FT/IR-4100 spectrometer; UV spectra were measured on a JASCO V-630 instrument; EI-MS were determined on a Hitachi M-2500 apparatus (70 eV, direct inlet system) and HRESI-MS were obtained on a JEOL JMS-T100LP mass spectrometer. ${ }^{1} \mathrm{H}-,{ }^{13} \mathrm{C}$-, and two-dimensional NMR spectra were acquired on a JEOL $\alpha 500\left({ }^{1} \mathrm{H}: 500 \mathrm{MHz},{ }^{13} \mathrm{C}: 125 \mathrm{MHz}\right)$ and a Bruker Avance III $500\left({ }^{1} \mathrm{H}: 500 \mathrm{MHz},{ }^{13} \mathrm{C}\right.$ : $\left.125 \mathrm{MHz}\right)$ spectrometers. Chemical shifts were given on a $\delta(\mathrm{ppm})$ scale with tetramethylsilane (TMS) as an internal standard. The symbols $\mathrm{s}, \mathrm{d}, \mathrm{t}, \mathrm{q}, \mathrm{dd}$ and $\mathrm{m}$ denote singlet, doublet, triplet, quartet, double doublet and multiplet, respectively. Flash-column chromatography (FC) were carried out on Kieselgel $60 \mathrm{~N} 40-50 \mu \mathrm{m}$ (Merck). Preparative thin layer chromatography (PTLC) was performed on a precoated Kieselgel $60 \mathrm{~F}_{254}$ plate (Merck). Ichthyotoxicity tests were performed in $150 \mathrm{~mL}$ of a test sample aqueous solution using male Japanese killifish (Oryzias latipes var.). ${ }^{23)}$

Extraction and Isolation The extraction and isolation of the constituents of the fresh leaves of $M$. triphylla were described in our previous paper. ${ }^{7)}$ Fraction III (26.90g) was divided into $\mathrm{C}_{6} \mathrm{H}_{6}$-soluble and $\mathrm{C}_{6} \mathrm{H}_{6}$-insoluble portions $(3.80 \mathrm{~g})$. The $\mathrm{C}_{6} \mathrm{H}_{6}$-soluble portion was purified by $\mathrm{FC}$ on a silica gel $\left(\mathrm{C}_{6} \mathrm{H}_{6}-\right.$ EtOAc gradient $)$ and PTLC on a silica gel $\left(8: 2 \mathrm{CHCl}_{3}\right.$ EtOAc) to yield 5 (11 mg), 3 (5 mg), 4 (12 mg), 6 (18 mg), 7 (18 mg), 1 (36 mg), and 8 (25 mg). The $\mathrm{C}_{6} \mathrm{H}_{6}$-insoluble portion was purified by $\mathrm{FC}$ on a silica gel $\left(\mathrm{C}_{6} \mathrm{H}_{6}-\right.$ EtOAc gradient $)$ and PTLC on a silica gel $\left(7: 3 \mathrm{CHCl}_{3}-\right.$ EtOAc) to yield $9(15 \mathrm{mg})$, 10 (28 mg), 11 (17 mg), and 2 (53 mg).

5,8-Dihydroxy-3,7-dimethoxy-3', $4^{\prime}$-methylenedioxyflavone (1): Yellow needles $\left(\mathrm{C}_{6} \mathrm{H}_{6}\right), \mathrm{mp} 256-257^{\circ} \mathrm{C} . \mathrm{Mg}-\mathrm{HCl}$ test: +. HR-ESI-MS m/z: $359.0781\left([\mathrm{M}+\mathrm{H}]^{+}, \mathrm{C}_{18} \mathrm{H}_{15} \mathrm{O}_{8}\right.$, Calcd 359.0767). IR $v_{\max }(\mathrm{KBr}) \mathrm{cm}^{-1}: 3300(\mathrm{OH}), 1655(\mathrm{C}=\mathrm{O})$. UV $\lambda_{\max }(\mathrm{MeOH}) \mathrm{nm}(\log \varepsilon): 259$ (4.09), 280 (4.14), 335 (4.00), $373 \mathrm{sh}(3.75) ; \lambda_{\max }\left(\mathrm{MeOH}+\mathrm{AlCl}_{3}\right) \mathrm{nm}(\log \varepsilon): 274 \mathrm{sh}(4.09)$, 288 (4.13), 328 (3.89), 364 (4.03), 438 (3.66); $\lambda_{\max }(\mathrm{MeOH}+$ $\left.\mathrm{AlCl}_{3}+\mathrm{HCl}\right) \mathrm{nm}(\log \varepsilon): 271 \mathrm{sh}(4.04), 288$ (4.11), 329 (3.92), 358 (4.01), 433 (3.58). EI-MS $m / z$ (rel. int. \%): $358\left[\mathrm{M}^{+}\right](100)$, $149\left[\left(\mathrm{OCH}_{2} \mathrm{O}\right) \mathrm{C}_{6} \mathrm{H}_{3}-\mathrm{C} \equiv \mathrm{O}^{+}\right](11) .{ }^{1} \mathrm{H}-\mathrm{NMR}$ : Table $1 .{ }^{13} \mathrm{C}-\mathrm{NMR}$ : Table 2.

7-Hydroxy-3,5-dimethoxy-3',4'-methylenedioxyflavone (2): Colorless needles $(\mathrm{MeOH}), \mathrm{mp} 274-276^{\circ} \mathrm{C} . \mathrm{Mg}-\mathrm{HCl}$ test: +. HR-ESI-MS m/z: $365.0642\left([\mathrm{M}+\mathrm{Na}]^{+}, \mathrm{C}_{18} \mathrm{H}_{14} \mathrm{NaO}_{7}, \mathrm{Calcd}\right.$ 365.0637). IR $v_{\max }$ (ATR: attenuated total reflection) $\mathrm{cm}^{-1}$ : $3125(\mathrm{OH}), 1609(\mathrm{C}=\mathrm{O})$. UV $\lambda_{\max }(\mathrm{MeOH}) \mathrm{nm}(\log \varepsilon): 269$ (4.11), 339 (4.00), 372 (4.00); $\lambda_{\max }(\mathrm{MeOH}+\mathrm{NaOAc}) \mathrm{nm}(\log \varepsilon)$ : 275 (4.44), 326 (4.29), 383 (4.25). EI-MS m/z (rel. int. \%): 342 $\left[\mathrm{M}^{+}\right](100), 323\left[\mathrm{M}^{+}-\mathrm{OH}_{3}\right](27), 149\left[\left(\mathrm{OCH}_{2} \mathrm{O}\right) \mathrm{C}_{6} \mathrm{H}_{3}-\mathrm{C} \equiv \mathrm{O}^{+}\right]$ (9). ${ }^{1} \mathrm{H}-\mathrm{NMR}$ : Table $1 .{ }^{13} \mathrm{C}-\mathrm{NMR}$ : Table 2.

7-(2,3-Dihydroxy-3-methylbutoxy)-3,5-dimethoxy-3',4'methylenedioxyflavone (3): A colorless amorphous powder. $\mathrm{Mg}-\mathrm{HCl}$ test: $+.[\alpha]_{\mathrm{D}}^{21}-10.1^{\circ}\left(c=0.10, \mathrm{CHCl}_{3}\right)$. HR-ESI-MS $m / z: 467.1325\left([\mathrm{M}+\mathrm{Na}]^{+}, \mathrm{C}_{23} \mathrm{H}_{24} \mathrm{NaO}_{9}\right.$, Calcd 467.1318). IR $v_{\max }(\mathrm{ATR}) \mathrm{cm}^{-1}: 3403(\mathrm{OH}), 1608(\mathrm{C}=\mathrm{O}) . \mathrm{UV} \lambda_{\max }(\mathrm{MeOH})$ $\mathrm{nm}(\log \varepsilon): 255$ sh (4.05), 264 sh (4.01), 292 (3.92), 330 (3.85). EI-MS $m / z$ (rel. int. \%): $444\left[\mathrm{M}^{+}\right](87), 425\left[\mathrm{M}^{+}-\mathrm{OH}_{3}\right](51)$, $341\left[\mathrm{M}^{+}-\mathrm{C}_{5} \mathrm{H}_{11} \mathrm{O}_{2}\right]$ (100), $149\left[\left(\mathrm{OCH}_{2} \mathrm{O}\right) \mathrm{C}_{6} \mathrm{H}_{3}-\mathrm{C} \equiv \mathrm{O}^{+}\right]$(49). ${ }^{1} \mathrm{H}-\mathrm{NMR}$ : Table $1 .{ }^{13} \mathrm{C}-\mathrm{NMR}$ : Table 2.

7-(2,3-Dihydroxy-3-methylbutoxy)-3,3',4',5-tetramethoxyflavone (4): A colorless amorphous powder. $\mathrm{Mg}-$ $\mathrm{HCl}$ test: $+.[\alpha]_{\mathrm{D}}^{21}-1.50^{\circ}\left(c=0.43, \mathrm{CHCl}_{3}\right)$. HR-ESI-MS $m / z$ : $483.1627\left([\mathrm{M}+\mathrm{Na}]^{+}, \mathrm{C}_{24} \mathrm{H}_{28} \mathrm{NaO}_{9}\right.$, Calcd 483.1631). IR $v_{\max }$ (ATR) $\mathrm{cm}^{-1}: 3421(\mathrm{OH}), 1615 \mathrm{sh}(\mathrm{C}=\mathrm{O}) . \mathrm{UV} \lambda_{\max }(\mathrm{MeOH})$ nm (log $\varepsilon): 250$ (4.27), 264 sh (4.21), 300 sh (4.04), 338 (4.17). EI-MS $m / z$ (rel. int. \%): $460\left[\mathrm{M}^{+}\right](100), 441\left[\mathrm{M}^{+}-\mathrm{OH}_{3}\right]$ (17), $357 \quad\left[\mathrm{M}^{+}-\mathrm{C}_{5} \mathrm{H}_{11} \mathrm{O}_{2}\right] \quad(20), 165 \quad\left[\left(\mathrm{OCH}_{3}\right)_{2} \mathrm{C}_{6} \mathrm{H}_{3}-\mathrm{C} \equiv \mathrm{O}^{+}\right] \quad$ (15). ${ }^{1} \mathrm{H}-\mathrm{NMR}$ : Table $1 .{ }^{13} \mathrm{C}-\mathrm{NMR}$ : Table 2.

7-(2,3-Dihydroxy-3-methylbutoxy)-3,3',4',5,8-pentamethoxyflavone (5): A colorless amorphous powder. $\mathrm{Mg}-\mathrm{HCl}$ test: $+[\alpha]_{\mathrm{D}}^{23}-5.27^{\circ}\left(c=0.06, \mathrm{CHCl}_{3}\right)$. HR-ESI-MS $m / z$ : $513.1750\left([\mathrm{M}+\mathrm{Na}]^{+}, \mathrm{C}_{25} \mathrm{H}_{30} \mathrm{NaO}_{10}\right.$, Calcd 513.1737). IR $v_{\max }$ (ATR) $\mathrm{cm}^{-1}: 3420(\mathrm{OH}), 1618(\mathrm{C}=\mathrm{O}) . \mathrm{UV} \lambda_{\max }(\mathrm{MeOH}) \mathrm{nm}$ ( $\log \varepsilon): 251$ (4.28), 272 (4.26), 299 sh (4.08), 348 (4.15). EI-MS $\mathrm{m} / \mathrm{z}$ (rel. int. \%): $490\left[\mathrm{M}^{+}\right](100), 471\left[\mathrm{M}^{+}-\mathrm{OH}_{3}\right]$ (21), 387 $\left[\mathrm{M}^{+}-\mathrm{C}_{5} \mathrm{H}_{11} \mathrm{O}_{2}\right](35), 165\left[\left(\mathrm{OCH}_{3}\right)_{2} \mathrm{C}_{6} \mathrm{H}_{3}-\mathrm{C} \equiv \mathrm{O}^{+}\right](8) .{ }^{1} \mathrm{H}-\mathrm{NMR}$ : Table 1. ${ }^{13} \mathrm{C}-\mathrm{NMR}$ : Table 2 .

3,4',5-Trihydroxy-3',7,8-trimethoxyflavone (6): A pale yellow amorphous powder. The ${ }^{1} \mathrm{H}-\mathrm{NMR}$ spectral data were identical with those in ref. 9 .

5,7-Dihydroxy-3-methoxy-3',4'-methylenedioxyflavone (7): Pale yellow needles $(\mathrm{MeOH}), \mathrm{mp} 270-272^{\circ} \mathrm{C}$ (lit. ${ }^{10)}$ $274-275^{\circ} \mathrm{C}$ ). Compound 7 was identified by examination of its IR, UV, EI-MS, ${ }^{1} \mathrm{H}$, and ${ }^{13} \mathrm{C}-\mathrm{NMR}$ spectra.

IR $v_{\max }(\mathrm{KBr}) \mathrm{cm}^{-1}: 3145(\mathrm{OH}), 1651(\mathrm{C}=\mathrm{O}) . \mathrm{UV} \lambda_{\max }$ $(\mathrm{MeOH}) \mathrm{nm}(\log \varepsilon): 256$ (4.26), 351 (4.23); $\lambda_{\max }(\mathrm{MeOH}+$ $\mathrm{NaOAc}) \mathrm{nm}(\log \varepsilon): 276$ (4.35), 320 (4.08), 374 (4.13); $\lambda_{\max }$ $\left(\mathrm{MeOH}+\mathrm{AlCl}_{3}+\mathrm{HCl}\right) \quad \mathrm{nm} \quad(\log \varepsilon): \quad 271 \quad(4.24), \quad 355 \quad(4.15)$, 399 (4.10). EI-MS m/z (rel. int. \%): $328\left[\mathrm{M}^{+}\right]$(100), 149 $\left[\left(\mathrm{OCH}_{2} \mathrm{O}\right) \mathrm{C}_{6} \mathrm{H}_{3}-\mathrm{C} \equiv \mathrm{O}^{+}\right](10) .{ }^{1} \mathrm{H}-\mathrm{NMR}$ (DMSO- $\left.d_{6}, 270 \mathrm{MHz}\right)$ $\delta: 3.78\left(3 \mathrm{H}, \mathrm{s}, \mathrm{OCH}_{3}-3\right), 6.15\left(2 \mathrm{H}, \mathrm{s}, \mathrm{OCH}_{2} \mathrm{O}-3^{\prime}, 4^{\prime}\right), 6.20(1 \mathrm{H}$, $\mathrm{d}, J=2.0 \mathrm{~Hz}, \mathrm{H}-6), 6.46(1 \mathrm{H}, \mathrm{d}, J=2.0 \mathrm{~Hz}, \mathrm{H}-8), 7.12(1 \mathrm{H}, \mathrm{d}$, $\left.J=8.5 \mathrm{~Hz}, \mathrm{H}-5^{\prime}\right), 7.56\left(1 \mathrm{H}, \mathrm{d}, J=2.0 \mathrm{~Hz}, \mathrm{H}-2^{\prime}\right), 7.63(1 \mathrm{H}, \mathrm{dd}$, $\left.J=8.5,2.0 \mathrm{~Hz}, \mathrm{H}-6^{\prime}\right), 12.59$ (1H, s, OH-5). ${ }^{13} \mathrm{C}-\mathrm{NMR}$ (DMSO$\left.d_{6}, 67.8 \mathrm{MHz}\right) \delta$ : $154.8(\mathrm{C}-2), 138.1$ (C-3), 177.9 (C-4), 161.2 
(C-5), 98.7 (C-6), 164.5 (C-7), 93.9 (C-8), 156.4 (C-9), 104.2

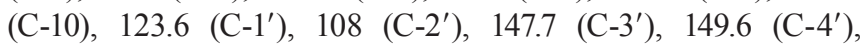
$108.6\left(\mathrm{C}-5^{\prime}\right), 123.5\left(\mathrm{C}-6^{\prime}\right), 59.8\left(\mathrm{OCH}_{3}-3\right), 101.9\left(\mathrm{OCH}_{2} \mathrm{O}-3^{\prime}, 4^{\prime}\right)$. 4',5,7-Trihydroxy-3,3'-dimethoxyflavone (8): Pale yellow plates $\left(\mathrm{CHCl}_{3}\right), \mathrm{mp} 248-250^{\circ} \mathrm{C}$ (lit. $\left.{ }^{11)} 230-232^{\circ} \mathrm{C}\right)$. The ${ }^{13} \mathrm{C}$-NMR spectral data were identical with those in ref. 11.

4',7-Dihydroxy-3,3',5,8-tetramethoxyflavone (9): Pale yellow needles $(\mathrm{MeOH}), \mathrm{mp} 240-242^{\circ} \mathrm{C}$ (lit. $\left.{ }^{12)} 244-246^{\circ} \mathrm{C}\right)$. The ${ }^{1} \mathrm{H}-\mathrm{NMR}$ spectral data were identical with those in ref. 12. ${ }^{1} \mathrm{H}-\mathrm{NMR}$ (DMSO- $\left.d_{6}, 400 \mathrm{MHz}\right) \delta: 3.75,3.78,3.84,3.86$ (each, $\left.3 \mathrm{H}, \mathrm{s}, \mathrm{OCH}_{3}\right), 6.45(1 \mathrm{H}, \mathrm{s}, \mathrm{H}-6), 6.97\left(1 \mathrm{H}, \mathrm{d}, J=8.5 \mathrm{~Hz}, \mathrm{H}-5^{\prime}\right)$, $7.59\left(1 \mathrm{H}, \mathrm{dd}, J=8.5,2.0 \mathrm{~Hz}, \mathrm{H}-6^{\prime}\right), 7.66(1 \mathrm{H}, \mathrm{d}, J=2.0 \mathrm{~Hz}$, $\left.\mathrm{H}-2^{\prime}\right)$.

4',7-Dihydroxy-3,3',5-trimethoxyflavone (10): Pale yellow needles $(\mathrm{MeOH}), \mathrm{mp} 256-258^{\circ} \mathrm{C}$. The ${ }^{1} \mathrm{H}-\mathrm{NMR}$ spectral data were identical with those in ref. 13 .

4',5,7-Trihydroxy-3,3',8-trimethoxyflavone (11): Yellow needles $(\mathrm{MeOH}), \mathrm{mp} 216-218^{\circ} \mathrm{C}$ (lit. ${ }^{9}{ }^{2} 215-217^{\circ} \mathrm{C}$ ). The ${ }^{1} \mathrm{H}-\mathrm{NMR}$ spectral data were identical with those in ref. 9.

Acknowledgements We are grateful for the financial support from the Research Seeds Program of Faculty of Science, University of the Ryukyus and Okinawa Science and Technology Promotion Center.

\section{References}

1) Higa M., Miyagi Y., Yogi S., Hokama K., Yakugaku Zasshi, 107, 954-958 (1987).

2) Jong T.-T., Wu T.-S., Phytochemistry, 28, 245-246 (1989).

3) Higa M., Ohshiro T., Ogihara K., Yogi S., Yakugaku Zasshi, 110, 822-827 (1990).

4) Hou R.-S., Duh C.-Y., Wang S.-K., Chang T.-T., Phytochemistry, 35,
271-272 (1994)

5) Jong T.-T., Wu T.-S., J. Chem. Res., 1989, 237 (1989), S.

6) Su T.-L., Lin F.-W., Teng C.-M., Chen K.-T., Wu T.-S., Phytother. Res., 12 (S1), S74-S76 (1998).

7) Higa M., Nakadomari E., Imamura M., Ogihara K., Suzuka T., Chem. Pharm. Bull., 58, 1339-1342 (2010).

8) Higa M., Imamura M., Shimoji K., Ogihara K., Suzuka T., Chem. Pharm. Bull., 60, 1112-1117 (2012).

9) Horie T., Tsukayama M., Kawamura Y., Yamamoto S., Phytochemistry, 27, 1491-1495 (1988).

10) Looker J. H., McMechan J. H., Mader J. W., J. Org. Chem., 43, 2344-2347 (1978).

11) Wang Y., Hamburger M., Gueho J., Hostettmann K., Phytochemistry, 28, 2323-2327 (1989).

12) Horie T., Tsukayama M., Kawamura Y., Seno M., J. Org. Chem., 52, 4702-4709 (1987).

13) Monache G. D., De Rosa M. C., Scurria R., Monacelli B., Pasqua G., Dall'Olio G., Botta B., Phytochemistry, 30, 1849-1854 (1991).

14) Wollenweber E., "The Flavonoids: Advances in Research," ed. by Harbone J. B., Mabry T. J., Chapman \& Hall, London, 1982, p. 240.

15) Kingston D. G. I., Tetrahedron, 27, 2691-2700 (1971).

16) Dhami K. S., Stothers J. B., Can. J. Chem., 44, 2855-2866 (1966).

17) Panichpol K., Waterman P. G., Phytochemistry, 17, 1363-1367 (1978).

18) Calvert D. J., Cambie R. C., Davis B. R., Org. Magn. Reson., 12, 583-586 (1979).

19) Roitman J. N., James L. F., Phytochemistry, 24, 835-848 (1985).

20) Horie T., Ohtsuru Y., Shibata K., Yamashita K., Tsukayama M., Kawamura Y., Phytochemistry, 47, 865-874 (1998).

21) Riveiro M. E., Maes D., Vázquez R., Vermeulen M., Mangelinckx S., Jacobs J., Debenedetti S., Shayo C., De Kimpe N., Davio C., Bioorg. Med. Chem., 17, 6547-6559 (2009).

22) Fraser A. W., Lewis J. R., Phytochemistry, 12, 1787-1789 (1973).

23) Higa M., Ogihara K., Yogi S., Chem. Pharm. Bull., 46, 1189-1193 (1998) 